\title{
BANQUET SPEECH \\ Full Circle: Star Ferry to Stardust
}

\author{
Clifford N. Matthews
}

Good evening. I'd like to invite you to join me on a journey that could be entitled "Full Circle: Star Ferry to Stardust". "Star Ferry" represents Hong Kong, my home town, and especially its university - Hong Kong University - as I knew it during the years of World War II. "Stardust" refers to our gathering here to report on our research on possible organic chemistry in space.

In late 1941, some 700 students of the arts and sciences, engineering and medecine lived and worked and played together on this cozy hillside campus. Though well aware of the Japanese presence in China, few, if any, could imagine that their lives would be transformed shortly by the onset of war. On December 8, 1941, Japanese troops occupying south China crossed the border of the New Territories and, using guerrilla tactics, soon had control of the whole peninsula of Kowloon. By December 18, they invaded the main Hong Kong island itself, crossing the harbor at Lyemun and North Point. Defending the colony were British troops - the Middlesex Regiment; Canadian forces - the Winnipeg Grenadiers and the Royal Rifles of Canada; an Indian regiment, and last but not least, the Hong Kong Volunteer Defense Corps. I was one of these Volunteers, who had been rapidly mobilized in response to the emergency, at the same time that I was a student of science at the university. The invaders fought their way up Wongneichong Gap and down to Repulse Bay, where fierce fighting took place just where we are sitting tonight. My unit, the Number 3 Machine Gun Company of the Volunteers, was stationed that night in concrete "pillboxes" on the hillside of the Gap, and suffered severe casualties.

My brother and I had been sent as couriers further up the Gap to warn the Canadians, who had only recently arrived in Hong Kong and hardly knew the terrain, of the Japanese landing. There I met up with other Volunteers and together 8 of us continued down to battle stations at the Wanchai waterfront - near where the opening reception of the Symposium was held last Sunday evening. There, on Christmas Day, we faced advancing Japanese troops who were heading for Central Hong Kong. We were prepared to make a final stand, and I remember thinking that this was going to be the last day of my life. Of course, this thought does not worry you during wartime. But suddenly and unexpectedly, a British officer appeared ahead of us, waving a white flag. Hong Kong had surrendered! All the defending troops were ordered to assemble on the Murray Parade Ground, on Garden Road. We then crossed over to Kowloon by ferry and marched several miles up Nathan Road, somewhat bedraggled, until we reached Sham Shui Po Barracks on the waterfront. There we were to become prisoners of war for the duration.

What happened to the university during those challenging times? An account is given in the book entitled Dispersal and Renewal: Hong Kong University during the War Years. You will notice on the cover of the book (Figure 1) a photograph of the Main Building, where we have met every day for the conference sessions, slightly damaged by air bombardment. The campus remained mostly empty during the occupation. What about the students and faculty? There were essentially 3 situations. Those who had fought as volunteers became prisoners of war. Non-combatant British faculty were interned at the civilian camp at Stanley, which many of you visited yesterday. Most of the students, who 
were predominantly Chinese, were not interned and many escaped into China. You will see on the cover of the book a photograph of a group of students who successfully made the trip through occupied China into Free China on foot and by boat, looking happy and relieved to have arrived. There were many such groups. Accustomed to speaking Cantonese, their first job was to learn Mandarin! In China, most of them taught or studied at Chinese universities.

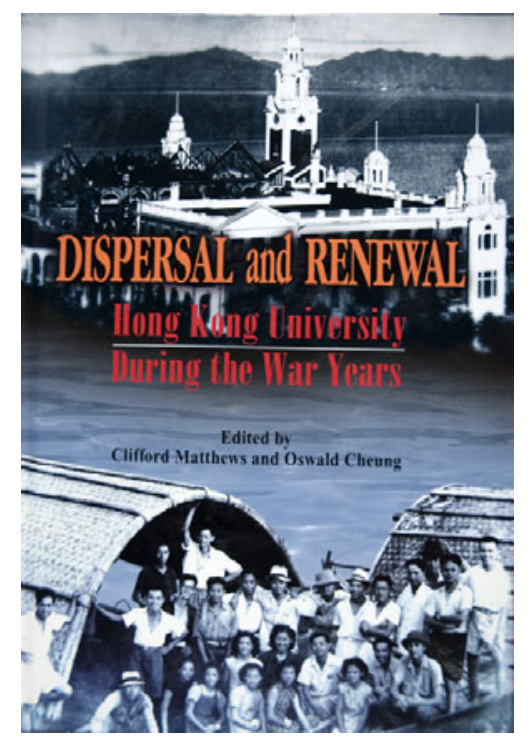

Figure 1.

Let's look at some individual examples of what Hong Kong University faculty and students experienced during the war. Lindsay Ride was a professor of physiology at the University and, during the war, commanded the medical unit of the Volunteers. He became a prisoner of war at Sham Shui Po, but not for long. With the help of his assistant Y.P. Lee, who brought a boat to the Sham Shui Po waterfront, he escaped through barbed wire and they made their way to Free China. There Ride founded the British Army Aid Group, an intelligence unit that operated in South China throughout the war. After the war, he rejoined the University, which had just been restarted by Vice Chancellor Duncan Sloss, and was elected the new vice Chancellor, a position he held for 15 very active years, during which he promoted the rapid growth of the university. Duncan Sloss himself was interned at Stanley. My mother and sister were also there, and remember well his inspiring intellectual presence. My sister even took a Shakespeare course with him.

In Figure 2 you see a reunion gathering in 1995 of former Hong Kong University students who were friends before the war. At the end of the war, a number of them were invited by the British Council to become graduate students at English universities. On the left in the back row, Oswald Cheung took a law degree in London, and returned to Hong Kong for a career in law and politics that earned him a knighthood. He was also the first Chinese to become head of the Hong Kong Jockey Club, where he used his influence to start the new University of Science and Technology in the New Territories.

Next to him is H.T. Huang, who had an unusual experience in China during the war. Teaching at Chengdu, he saw a notice one day announcing the arrival of Joseph Needham, a scientist from Cambridge University, whose mission was to assist Chinese universities 


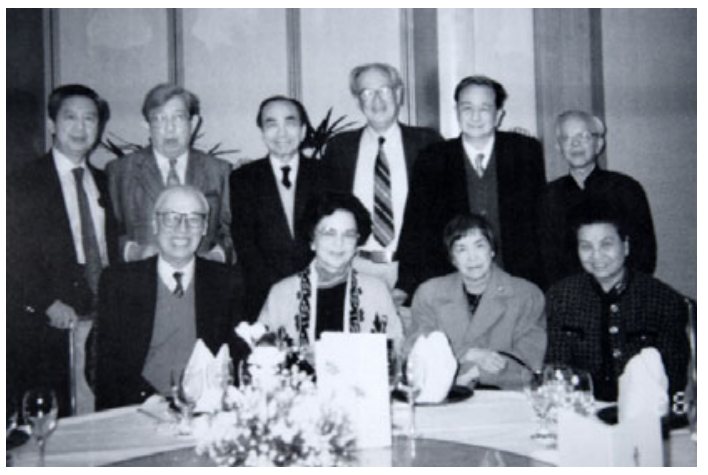

Figure 2.

in any way possible. H.T. became his driver and translator, and for a year and a half they visited Chinese universities, at the same time frequenting bookstores in back streets where they found many manuscripts on science in China. Returning to Cambridge after the war, Needham planned to publish a slim volume on science and civilization in China. Instead this became a lifetime endeavor; there are now over 20 books in print and 3 more to come. While working after the war at the National Science Foundation in the U.S., H.T. Huang remained an active collaborator on this profound scholarly project, authoring the section entitled "Fermentations and Food Science".

Also in the reunion group is Rayson Huang. Originally a science student at Hong Kong University (I was his lab partner in chemistry), Rayson went on, like H.T., to obtain his PhD. at Oxford working with Sir Robert Robertson. Returning to Asia, he became first a professor of chemistry at Kuala Lumpur and then the first Vice Chancellor of the new Nanyang University in Singapore. From there, he received an offer he could not refuse - to become Vice Chancellor of Hong Kong University, his alma mater. During his 14 years as Vice Chancellor, he met with Deng Xiao Ping, China's Premier, to discuss the imminent return of Hong Kong to China. Upon retiring, Rayson Huang continued to be active on the committee that drafted the Basic Law for Hong Kong, establishing the principle of "One Country: Two Systems".

His distinguished career as the first Chinese Vice Chancellor of the University shows the great change in Hong Kong after the war. Before the war, the Vice Chancellor of the University would have been brought in from England. After the war, local Chinese were able to take on many leadership positions, and Hong Kong became what it still is today - a multi-cultural center bridging East and West.

At our reunion, I recall us discussing the possibility that there should be a memorial of some kind to the members of the University community who lost their lives during the war. One idea was to erect a memorial fountain on campus. Another was to have a special room in the library devoted to wartime themes. What actually happened was the publication of the book I have already mentioned, which brings together reminiscences by many alumni and former faculty. I became the editor and my old school and university friend Oswald Cheung assisted, particularly with the graphics. On the dedication page of the book we named all those who lost their lives as a result of the war.

Of all those at the reunion, I was the only one who was not in China during the war, because I was a POW. At Sham Shui Po I was working alongside thousands of other prisoners at tasks such as building a new runway at Kai Tak Airport. After about a year, unexpectedly, a hundred Volunteers, including my brother and I, were chosen to be sent as POWs to Japan, to an island called Innoshima, in the Inland Sea about 40 miles south 
of Hiroshima. There we met a hundred other British POWs from Java and Singapore, and we all worked together in the Habu Ship-Building Yard. We lived in wooden barracks such as those pictured in this cartoon by a fellow prisoner (Figure 3). Thirty-two of us were in each room, sleeping on tatamis in bunk beds. Early each morning we would march down to the dock yard to take up our work positions. My group of 6 worked in the foundry, where we threw scrap metal into the furnace to make ingots - a nice job in the winter! Fortunately one of us spoke Japanese from previous experience in Japan, and this enabled us to communicate somewhat with our 4 Japanese supervisors, who we soon grew to respect and appreciate as individuals.

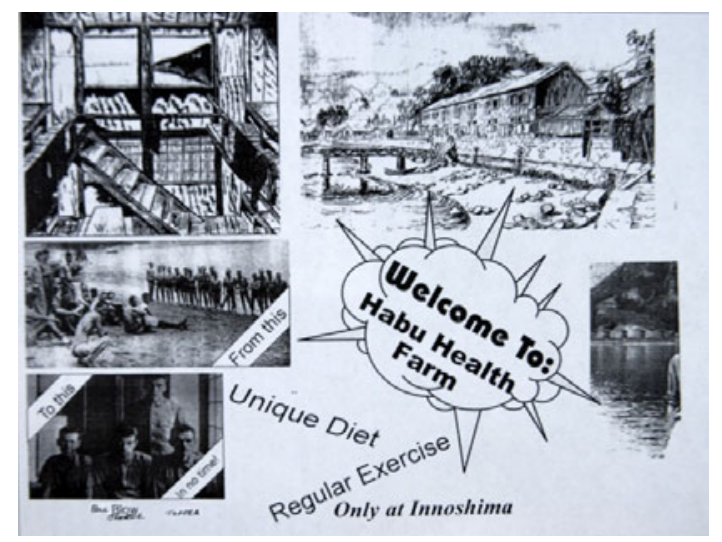

Figure 3.

Most dramatic was V-J day. When we reached the dockyard that morning, we were told not to enter, but to wait outside. Inside, the emperor was about to broadcast on the radio for the first time in history. When we heard that he had announced the Japanese surrender, we immediately returned to our camp, tore down the wooden fence that surrounded it, and roamed around the island for the first time, bringing back chickens and vegetables. We had our first chicken dinner in Japan that night.

I decided not to return to Hong Kong, since the University was not yet functioning, but to complete my studies in England. There, I joined Birkbeck College at London University, where I took classes at night and worked during the day as the chemistry laboratory superintendant. Most inspiring for me was the presence of the physics professor John Desmond Bernal, arguably the most eminent British scientist of that era. A recent biography has appeared entitled J.D. Bernal: the Sage of Science. (Figure 4). He was known as sage because of his wide interest in all aspects of science and its role in society. Before the war, he started X-ray crystallography on proteins; during the war he was a major advisor on the Normandy landing and later became scientific advisor to Lord Louis Mt. Batten in the Asian theater. After the war in London, his research included studies on the structure of water, cement, cosmic rays and viruses. He also started research on meteorites arising from his newfound interest in the origin of life, influenced by the early writings of the biochemists Alexander Oparin in Russia and J.B.S. Haldane in England.

In 1947 Bernal gave his famous Guthrie lecture on the origin of life. I was there in the audience at Imperial College, and was amazed to think that one could study such a profound subject through laboratory experiments. I was especially struck by Bernal's insistence on the importance of investigating the structure and origin of proteins, an idea which stuck with me throughout the following years, when I earned my PhD. at Yale followed by fundamental research in industry on hydrogen cyanide. This research brought 


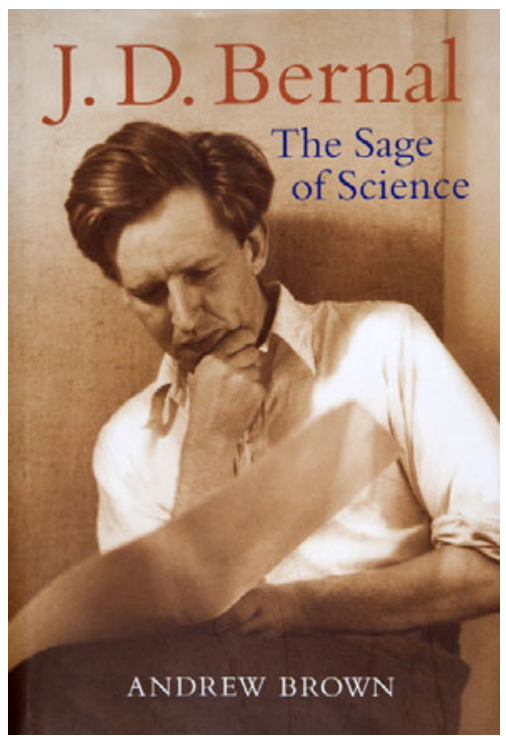

Figure 4 .

together for me the connection between hydrogen cyanide and the origin of life, which I continued to pursue through further research at the University of Illinois at Chicago and more recently at Penn State in collaboration with Robert Minard. Tomorrow I will be lecturing on our model, which states that hydrogen cyanide polymers are the bridge between cosmochemistry and biochemistry.

The great interest in Bernal's lecture led him to write his definitive volume on the origin of life, a necessary background to the founding of ISSOL - the International Society for the Study of the Origin of Life - and its journal "The Origins of Life and Chemical Evolution". Bernal, Oparin and Haldane actually took part in early meetings of ISSOL. International gatherings, such as those of ISSOL and the IAU, not only bring scientists together here on Earth, but remind us that ultimately we, and all life, are recycled stardust.

Encore: Enjoying this banquet, I couldn't help but be reminded of the meager diet we had as POWs in Japan. All POWs are obsessed with food: they think food, they talk food, they dream food, and they even sing food, as I shall demonstrate by singing this song, entitled "Protein Deficiency", written by Ted Tandy, brother of the acress Jessica Tandy. Here goes:

There'd be nothing wrong with life on the Inland Sea, If only I could have a poached egg for my tea.

The local lads stick to rice and fish, quite forgetting that an egg makes a tasty dish. In the days before the war I'd have an egg with every meal, but when eggplant supplanted egg my sufferings were real.

For breakfast I used to have ham and eggs; now I have yam and eggplant stew.

I never used to suffer from swollen legs; that's a thing that an egg-fed leg won't do. For dinner I would have an underdone rump steak, with a nice poached egg on the top.

For tea I would boil em, for boiling doesn't spoil em,

And there perhaps you'd think that I would stop, but NO! 
I love to think of suppers in the days before the war

When I'd have a dozen fried and then tell Ma to fry some more.

In the far future days when the Inland Sea is nothing more to us than a memory,

There'll be eggs in my marmalade and eggs in my tripe,

I'll drink them in my beer and I'll smoke them in my pipe.

Every Friday night I'll bath in eggs before I go to bed, and I'll have a kidney omelet in my coffin when I'm dead.

There'll always be an England, and what England means to me is

Steak and chips and two fried eggs and a nice hot cup o' tea.

\section{Acknowledgements}

I would like to thank Sun Kwok, Bill Irvine and Sandra Matthews for their considerable assistance, making it possible for me, legally blind, to take part in this stimulating symposium. 